\title{
Penyelesaian Sengketa Kredit Macet Melalui Pelaksanaan Pelelangan Aset Debitur Oleh PT. Bank Artha Graha Internasional, Tbk Medan
}

\author{
Michael Willy Chandra, Sutiarnoto, Ida Nadirah
}

Program Studi Magister Kenotariatan

Universitas Muhammadiyah Sumatera Utara

Jl. Denai No. 217 Medan 20226 Telp: (061) 88811104

Email: michaelwillyc@yahoo.co.id (CA)

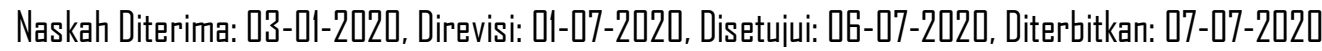
DDI: https://dai.org/I0.30596/dll.v5i2.4084
\end{abstract}

\begin{abstract}
Abstrak
Lembaga perbankan sebagai salah satu lembaga keuangan mempunyai kedudukan yang strategis karena ikut berperan penting dalam penyediaan dana atau kredit yang di butuhkan untuk membiayai kegiatan-kegiatan dibidang perekonomian, selain masih merupakan sumber dana primer bagi kebanyakan orang. Pihak bank dalam rangka penyelesaian sengketa ini tidak jarang mengambil langkah melakukan pelelangan aset debitur yang dijadikan jaminan dalam perjanjian kredit. Metode penelitian yang digunakan yaitu dengan jenis penelitian hukum normatif. Permasalahan yang diangkat pada penelitian ini, yakni bagaimana kedudukan aset debitur sebagai jaminan dalam perjanjian kredit, proses penyelesaian sengketa kredit macet melalui pelaksanaan lelang aset debitur, dan mekanisme pelelangan aset debitur terkait penyelesaian kredit macet antara nasabah dengan pihak PT. Bank Artha Graha Internasional, Tbk Medan. Hasil penelitian menunjukkan bahwa eksistensi aset debitur sebagai jaminan dalam perjanjian kredit pada PT. Bank Artha Graha Internasional, Tbk Medan yang digunakan untuk penyelesaian sengketa kredit macet merupakan upaya bank untuk mengambil pelunasan perjanjian kredit dengan penjualan aset jaminan debitur melalui metode lelang eksekusi berdasarkan UndangUndang Nomor 4 Tahun 1996.
\end{abstract}

Kata Kunci: Penyelesaian Sengketa, Lelang Jaminan, Debitur.

\begin{abstract}
Financial institutions as one of the financial institutions have a strategic position because they participate in the provision of funds or credit needed to finance activities in the financial sector, besides that it is still a primary source of funds for everyone. Banks in the framework of this agreement often take steps to auction assets. The research method used is the type of normative legal research. Problems raised in this study, namely regarding the position of the debtor's assets as collateral in the credit agreement, the process of settlement of bad debts through the implementation of the debtor's asset auction, and auctioning auction assets related to Bank Artha Graha Internasional, Tbk Medan. The results showed that the existence of the debtor's assets as collateral in a credit agreement with PT. Bank Artha Graha Internasional, Tbk. Medan is used to settle bad credit disputes which is a bank's help to take repayment of credit agreements with the sale of assets of the debtor's guarantee through the auction auction method based on Law Number 4 of 1996.
\end{abstract}

Keywords: Dispute Settlement, Auctions, Guarantees, Debtors. 


\section{PENDAHULUAN}

Bank sebagai salah satu lembaga keuangan yang paling penting dan besar peranannya dalam kehidupan perekonomian masyarakat, di mana dalam menjalankan peranannya, bank bertindak sebagai salah satu bentuk lembaga keuangan yang bertujuan memberikan kredit, dan jasa-jasa lainnya. Sebagaimana dalam Pasal 1 angka 1 Undang-Undang Nomor 10 Tahun 1998 tentang Perbankan "Perbankan adalah segala sesuatu yang menyangkut tentang bank, mencakup kelembagaan, kegiatan usaha, serta cara dan proses dalam melaksanakan kegiatan usahanya".

Dana yang diterima dari masyarakat, apakah itu berbentuk simpanan berupa tabungan, giro, atau deposito, pada akhirnya diedarkan kembali oleh bank, misalnya lewat pasar uang (money market), pendepositoan investasi dalam bentuk lain dan terutama dalam pemberian kredit kepada nasabah (Djumhana, 2000, h. 298). Kredit dalam kegiatan perbankan merupakan kegiatan usaha yang paling utama, karena pendapatan terbesar dari usaha bank, berasal dari pendapatan kegiatan usaha kredit, yaitu berupa bunga dan provisi.

Menurut Pasal 1 angka 11 Undang-Undang Nomor 10 Tahun 1998 Tentang Perbankan, dinyatakan bahwa kredit adalah penyediaan uang atau tagihan yang dapat dipersamakan dengan itu, berdasarkan persetujuan atau kesepakatan pinjam-meminjam antara bank dengan pihak lain yang mewajibkan pihak peminjam untuk melunasi setelah jangka waktu tertentu dengan pemberian bunga.

Masayarakat sejak lama mengenal istilah pinajam meminjam uang, dan kegiatan inipun sudah lama di kenala dalam kehidupan masyarakat di mana masyarakat telah menjadikan kegiatan pinjam-meminjam uang sebagai sesuatu yang sangat diperlukan untuk mendukung perkembangan kegiatan ekonominya atau meningkatkan taraf kehidupannya. Para pihak pemberi pinjaman yang mempunyai kelebihan uang bersedia memberikan pinjaman kepada yang memerlukannya. Sebaliknya pihak peminjam berdasarkan keperluan atau tujuan tertentu melakukan peminjaman uang tersebut, dan dengan demikian kegiatan pinjam-meminjam uang sudah merupakan bagian dari kehidupan masyarakat (Djumhana, 2000, h. 2). Beberapa pihak yang lazimnya menjadi pemberi pinjaman kepada nasabah yaitu perbankan maupun perusahaan-perusahaan pemberi kredit melalui jaminan-jaminan barang yang dijaminkan oleh debitur salah satunya mengenai kredit macet yang berpengaruh terhadap pendapatan yang dialami oleh PT. Bank Artha Graha Internasional, Tbk yang akan diulas dalam penelitian ini.

Unsur yang penting dalam kredit adalah adanya kepercayaan dan yang lainnya adalah sifat atau pertimbangan saling tolong-menolong, jika dilihat dari pihak kreditur, maka unsur yang paling penting dalam kegiatan kredit sekarang ini adalah untuk mengambil keuntungan dari modalnya dengan mengharapkan pengembalian prestasi, sedangkan bagi debitur adalah bantuan dari kreditur untuk menutupi kebutuhannya berupa prestasi yang diberikan kreditur,hanya saja antara prestasi dengan pengembalian prestasi tersebut ada suatu masa yang memisahkannya, sehingga terdapat tenggang waktu tertentu.

Kondisi ini mengakibatkan adanya resiko, berupa ketidaktentuan pengembalian prestasi yang telah diberikan, oleh karena itu diperlukan suatu jaminan dalam pemberian kredit tersebut.Badan usaha umumnya secara tegas mensyaratkan kepada pihak peminjam untuk menyerahkan suatu barang (benda) sebagai objek jaminan utang pihak peminjam. Jaminan utang yang di tawarkan (diajukan) oleh pihak peminjam umumnya akan di nilai oleh badan 
usaha tersebut sebelum diterima sebagai objek jaminan atas pinjaman yang di berikannya. Penilaian yang seharusnya dilakukan sebagaimana yang biasa terjadi di bidang perbankan meliputi penilaian dari segi hukum dan dari segi ekonomi. Berdasarkan penilaian dari kedua segi tersebut di harapkan akan dapat disimpulkan kelayakan sebagai jaminan utang yang baik dan berharga.

Jaminan itu adalah suatu keyakinan bank atas kesanggupan debitur untuk melunasi kredit sesuai dengan yang diperjanjikan." (Pasal 2 Ayat (1) Surat Keputusan Direksi Bank Indonesia Nomor 23/69/Kep/Dir Tentang Jaminan Pemberian Kredit). Jaminan yang ideal (baik) tersebut terlihat dari hal-hal yaitu:

1. Dapat secara mudah membantu perolehan kredit oleh pihak yang memerlukannya.

2. Tidak melemahkan potensi (kekuatan) si penerima kredit untuk melakukan (meneruskan) usahanya.

3. Memberikan kepastian kepada kreditur dalam arti bahwa mudah diuangkan untuk melunasi utangnya si debitur.

Menurut Teguh Syuhada Lubis dalam Jurnal Delegalata, menyebutkan bahwa sita jaminan atas benda bergerak dapat terjadi apabila perjanjian kredit tidak dijamin dengan agunan barang tertentu atau jaminannya berbentuk fidusia. Penjelasan tentang hal itu, tidak memerlukan uraian lagi, karena pada dasarnya sama dengan prinsip umum yang dijelaskan pada prinsip-prinsip pokok penyitaan (Lubis, 2019, h. 47).

Kredit yang diberikan oleh bank tentu saja mengandung resiko, sehingga dalam pelaksanaannya bank harus memperhatikan asas-asas perkreditan yang sehat. Untuk mengurangi resiko tersebut, jaminan pemberian kredit dalam arti keyakinan atas kemampuan dan kesanggupan debitur untuk melunasi kewajibannya sesuai dengan yang diperjanjikan merupakan faktor penting yang harus diperhatikan oleh bank, di mana untuk memperoleh keyakinan tersebut, sebelum memberikan kredit, bank harus melakukan penilaian yang seksama terhadap watak, kemampuan, modal agunan, dan prospek usaha dari debitur, apabila unsur-unsur yang ada telah dapat meyakinkan kreditur atas kemampuan debitur maka jaminan cukup hanya berupa jaminan pokok saja dan bank tidak wajib meminta jaminan tambahan (Hermansyah, 2005, h. 68).

Kredit yang diberikan oleh bank, dimaksudkan untuk memberikan penyediaan uang yang di dasarkan atas perjanjian pinjam-meminjam yang dilakukan antara pihak bank sebagai kreditur dengan pihak nasabah atau masyarakat sebagai debitur. Dari pengertian itu dapat diketahui bahwa dalam perjanjian kredit diperlukan adanya suatu jaminan yang diberikan pada bank. Jaminan yang diberikan tadi diperlukan karena dengan adanya jaminan ini akan ada suatu kepastian kredit yang telah diberikan, untuk di kembalikan sesuai jangka waktu yang disepakati, dan telah dituangkan di dalam perjanjian kredit.

Pelaksanaan perjanjian kredit antara pihak bank dengan nasabah tidak selamanya berjalan dengan baik, di mana dalam beberapa kasus ditemukan nasabah tidak sanggup membayar cicilan dan melunasi pinjaman kredit bank dan tidak jarang akibat dari kredit macet ini berujung terjadinya sengketa antara pihak bank dan nasabah. Pihak bank dalam rangka penyelesaian sengketa ini tidak jarang mengambil langkah melakukan pelelangan aset debitur yang dijadikan jaminan dalam perjanjian kredit.

Metode lelang eksekusi berdasarkan Undang-Undang Nomor 4 Tahun 1996 Tentang Hak Tanggungan Atas Tanah Beserta Benda-Benda Yang Berkaitan Dengan Tanah, dan Undang- 
Undang Nomor 42 Tahun 1999 tentang Jaminan Fidusia ialah melalui parate eksekusi, yaitu pemegang hak tanggungan, dalam hal ini bank, menjual obyek hak tanggungan melalui pelelangan umum serta mengambil pelunasan piutang dari hasil pelelangan umum tersebut.

Dalam kaitan objek perjanjiannya adalah hak atas tanah dan bangunan, maka konsep perjanjian BOT merupakan salah satu bentuk modifikasi penggunaan dan pemanfaatan hak atas tanah dengan adanya pendirian bangunan di atas tanah hak milik orang lain sebagai sebuah produk politik hukum pertanahan Indonesia yang menganut asas pemisahan horizontal, dimana membuka peluang terciptanya kepemilikan yang berbeda antara tanah dan bangunannya atau bagian yang terdapat pada permukaan tanah dimaksud (Ramadhani, 2019, h. 263).

Berdasarkan data terkait sengketa kredit macet pada PT. Bank Artha Graha Internasional, TbkMedan ditemukan setidaknya 9 (sembilan) kasus dalam kurun waktu tiga tahun terkahir terkait nasabah yang terindikasi kreditnya macet dan 3 (tiga) dari 9 (sembilan) kasus tersebut telah dilaksanakan pelelangan aset debitur oleh bank sebagai langkah penyelesaian sengketa macet. Pada pelaksanaan pelelangan aset debitur permasalahan yang sering terjadi adalah bank selalu menghadapi gugatan balik dari debitur yang tidak ingin agunannya dilelang.

Gugatan tersebut didasarkan bahwa bank melakukan lelang tanpa ada persetujuan terlebih dahulu dari debitur, padahal dalam akta perjanjian sudah tercantum apabila debitur wanprestasi, bank akan melakukan tindakan untuk mengembalikan aset bank termasuk upaya lelang, hal inilah yang sering menjadi sengketa antara bank dengan debiturnya, di mana debitur merasa tindakan lelang yang dilaksanakan oleh pihak perbankan merupakan tindakan yang melawan hukum.

Penelitian ini difokuskan untuk melihat praktik perjanjian kredit antara nasabah dengan PT. Bank Artha Graha Internasional, Tbk Medandan juga untuk melihat keabsahan pelelangan di mana pihak bank melakukan pelelangan aset debitur sebagai langkah penyelesaian sengketa kredit macet. Berdasarkan hal tersebut, penelitian ini diberi judul 'Penyelesaian Sengketa Kredit Macet Melalui Pelaksanaan Pelelangan Aset Debitur Oleh PT. Bank Artha Graha Internasional, Tbk Medan'.

\section{METODE PENELITIAN}

Menurut Meuwissen metode yang digunakan ilmu hukum empiris adalah metode ilmu empiris selanjutnya HLA Hart (1997) berpendapat bahwa melalui kajian empiris maka dapat dilakukan observasi secara indrawi, keabsahan dapat diverifikasi dengan kajian empiris untuk menghasilkan suatu pengetahuan. Sifat dari penelitian ini adalah deskritif analisis, artinya dalam penulis hanya ingin menggambarkan kebijakan-kebijakan yang dilakuan pihak pembuat kebijakan dalam hal ini pemerintah terhadap ketentuan yang mengatur tentang perjanjian kredit. Metode penelitian deskriptif analitis adalah suatu metode yang berfungsi untuk mendeskripsikan atau memberi gambaran terhadap objek yang diteliti melalui data atau sampel yang telah terkumpul sebagaimana adanya tanpa melakukan analisis dan membuat kesimpulan yang berlaku untuk umum, dengan kata lain penelitian deskriptif analitis mengambil masalah atau memusatkan perhatian kepada masalah-masalah sebagaimana adanya saat penelitian dilaksanakan, hasil penelitian yang kemudian diolah dan dianalisis untuk diambil kesimpulannya (Sugiyono, 2009, h. 29). Lokasi penelitian ini dilakukan di PT. Bank Artha Graha Internasional. Tbk Medan. Populasi adalah keseluruhan dari variabel yang menyangkut masalah yang diteliti yang terdiri atas obyek atau subyek yang mempunyai kualitas dan 
karakteristik tertentu yang ditetapkan oleh peneliti untuk dipelajari dan kemudian ditarik kesimpulannya, sedangkan sampel adalah sebagian untuk diambil dari keseluruhan obyek yang diteliti dan dianggap mewakili seluruh populasi.

\section{PEMBAHASAN DAN ANALISIS \\ Kedudukan Aset Debitur Sebagai Jaminan Kredit Perbankan Dengan Perjanjian Menggunakan Klausula Baku}

Pada perkembangan perbankan modern, kredit tidak terbatas pada peminjaman atau pembiayaan melalui mekanisme yang lebih sederhana berupa transaksi penyerahan uang tunai secara langsung kepada debitur, namun saat ini transaksi di bidang kredit menggunakan prosedur, mekanisme, dan instrumen yang lebih kompleks, namun memudahkan kreditur dan debitur bertransaksi.Memperhatikan kompleksitas prosedur, mekanisme, instrumen, juga permasalahannya, maka sangat wajar dan tidak berlebihan apabila pengertian kredit yang begitu luas sebagaimana tercantum yaitu: (Pedoman Penyusunan Kebijaksanaan Perkreditan Bank (PPKPB) Bank Indonesia)

"Pengertian kredit tidak terbatas hanya pada pemberian fasilitas kredit yang lazim dibukukan dalam pos kredit pada aktiva dalam neraca bank, namun termasuk pula pembelian surat berharga lain yang diterbitkan nasabah, pengambilan tagihan dalam rangka anjak piutang, dan pemberian jaminan bank yang di antaranya, meliputi akseptasi, endosemen, dan aval surat-surat berharga."

Pengertian kredit yang disebut di atas begitu luas di mana pengertian tersebut menggambarkan cakupan transaksi ekonomi dan keuangan di mana kreditur menyerahkan suatu nilai kepada debitur dan sebaliknya, debitur berjanji akan mengembalikannya pada waktu yang telah ditetapkan pada masa depan.Adapun nilai yang diserahkan tersebut berupa uang, jasa-jasa, barang, atau klaim keuangan, seperti obligasi atau comercial paper, dan saat ini begitu kompleksnya kegiatan yang menyangkut kredit tersebut berbeda sekali dengan saat awal berkembangnya kredit. Kredit pada awal perkembangannya adalah suatu kegiatan pinjammeminjam bermula karena adanya kepercayaan di antara mereka, yaitu si pemberi pinjaman percaya bahwa si peminjam akan mengembalikan pinjamannya (baik dengan disertai bunga maupun tidak disertai bunga) pada saat yang telah dijanjikan.

Pemberian kredit dapat dilaksanakan ketika ada persetujuan atau perjanjian antara bank sebagai kreditur dengan nasabah penerima kredit sebagai debitur yang disebut perjanjian kredit. Mengingat pentingnya kedudukan dana perkreditan tersebut dalam proses pembayaran, sudah semestinya jika pemberi kredit dan penerima kredit serta pihak lain yang terkait mendapat perlindungan melalui suatu lembaga jaminan yang kuat dan yang dapat pula memberikan kepastian hukum bagi semua pihak (Wawancara, Sitompul).

Perkara pelunasan hutang kadang-kadang di dalam waktu pelaksanaan sita jaminan ada pihak ketiga yang mengaku bahwa barang yang disengketakan tersebut adalah miliknya. Sehingga pelaksanaan sita jaminan dalam beberapa perkara kasus objek yang hendak disita merupakan warisan yang belum terbagi waris dan pihak ketiga tersebut merupakan ahli waris yang berhak pula atas barang yang disita. Sehingga kepentingan hukum atas barang tersebut terganggu dengan adanya sita jaminan tersebut. Di dalam pelaksanaan di tempat barang tersebut berada belum tentu berjalan mulus (Lubis, 2019, h. 44). 
Pada praktik perbankan, sering di jumpai bank telah menyediakan formulir atau blanko perjanjian kredit, di mana formulir tersebut diberikan pada setiap pemohon kredit yang isinya tidak diperbincangkan melainkan setelah dibaca oleh pemohon, pihak bank hanya meminta pendapat calon nasabah, apakah dapat menerima syarat-syarat yang tersebut dalam formulir itu atau tidak, sedangkan hal-hal yang kosong di dalam formulir, seperti jumlah pinjaman, besarnya bunga, tujuan pemakaian kredit, dan jangka waktu kredit adalah hal-hal yang tidak mungkin diisi sebelum ada persetujuan dari kedua belah pihak.

Badrulzaman berpendapat bahwa ormulir atau blanko perjanjian kredit bank merupakan bentuk perjanjian baku dan adapun ciri-ciri perjanjian baku adalah sebagai berikut:

1. Isi atau syarat yang diperjanjikan telah ditetapkan secara sepihak.

2. Masyarakat sama sekali tidak dapat menentukan isi atau syarat yang diperjanjikan.

3. Masyarakat terdorong oleh kebutuhan terpaksa menerima isi atau syarat yang diperjanjikan, sehingga apabial kemudian akan mengadakan perubahan isi atau syarat tersebut sama sekali tidak bisa.

4. Isi atau syarat yang diperjanjikan telah dipersiapkan terlebih dahulu

Perjanjian kredit ini mengandung kelemahan terutama dihubungkan dengan Pasal 1320 dan 1338 KUHPerdata, karena dalam perjanjian kredit tidak mengandung adanya kesepakatan dalam arti luas dari kedua belah pihak, melainkan hanya sepihak. Sedangkan pihak pemohon dalam memberi kesepakatannya hanya fiktif belaka. Dengan demikian perjanjian kredit tidak hanya mengandung kelemahan tetapi sekaligus menyimpang dari asas-asas yang terkandung dalam Pasal 1320, Pasal 1338 KUH Perdata. Selanjutnya UU Perlindungan Konsumen pun melarang adanya klausul baku sehingga harus ada informasi yang jelas terutama dalam hal status aset yang dijaminkan.

Terlepas dari kelemahan dari penyimpangan Pasal 1320, Pasal 1338 KUH Perdata, sebab disatu segi, timbulnya perjanjian (standart) kredit tidak dilatarbelakangi oleh kaum ekonomi kuat, tetapi oleh kemauan pemerintah untuk membantu dan merangsang pertumbuhan pengusaha ekonomi lewat bantuan kredit, sedangkan disisi lain pemberian atau pelepasan kredit tanpa disertai adanya persyaratan yang ketat akan mengakibatkan terbukanya resiko yang besar bagi kelangsungan usaha bank dan pada akhirnya akan melumpuhkan tujuan yang terkandung dalam pemberian kredit itu sendiri.

Pada praktik perbankan, secara yuridis formal terdapat dua jenis perjanjian kredit yang digunakan bank dalam melepas kreditnya sebagaimana pendapat Sjahdeni, yaitu:

1. Akta atau perjanjian kredit di bawah tangan, adalah perjanjian pemberian kredit oleh bank kepada nasabahnya yang hanya dibuat di antara mereka (kreditur dan debitur) tanpa notaris. 2. Akta atau perjanjian kredit notariil (autentik), adalah perjanjian yang dibuat secara notariil dalam pemberian kredit kepada nasabahnya yang dibuat di hadapan notaris.

Bank dalam memberikan kredit pada nasabah harus melihat prinsip-prinsip standar dalam memahami nasabah, di mana prinsip tersebut dapat dilakukan dengan sistem penilaian terhadap watak, kemampuan, modal, dan prospek usaha dari nasabah debitur tersebut dikenal dengan istilah the five of credit analysis yang merupakan ukuran kemampuan penerima kredit (debitur) untuk mengembalikan pinjamannya, yaitu: (Kasmir, h. 140).

1. Kemampuan (capacity).

2. Watak (character).

3. Kondisi ekonomi (condition of economy). 


\section{Modal (capital).}

\section{Jaminan (collateral).}

Unsur utama dan pertama dari kredit yaitu unsur kepercayaan dan unsur yang lainnya hanya bersifat sebagai penunjang dari unsur pertama dan utama tersebut, dalam arti unsur tersebut berguna dalam rangka pertimbangan yang menyeluruh dalam mendapatkan atau memperoleh keyakinan dan kepercayaan untuk terjadinya suatu hubungan atau perikatan hukum dalam bidang perkreditan tersebut dan unsur penunjang yang dimaksud disini adalah benda jaminan yang diberikan nasabah kepada bank baik dalam bentuk surat, benda bergerak maupun benda tidak bergerak.

Berdasarkan dengan adanya jaminan baik dalam bentuk surat, benda bergerak maupun benda tidak bergerak, sudah cukup bagi pihak bank untuk memberikan kredit kepada nasabah tersebut (Wawancara, Sitompul). Namun kondisi seperti ini, masih sangat mungkinterjadinya kredit macet, karena pembayaran kredit tidak serta merta secara langsung dipotong dari gaji yang diterima oleh nasabah atau debitur, di mana tidak semua jaminan pokok atau sumber pengembalian kredit berasal dari penghasilan gaji atau pensiunan nasabahdan pada umumnya nasabah selain pegawai tidak menyerahkan surat kuasa kepada bank untuk memotong gaji atau mendebet rekening tabungan untuk angsuran kredit (Wawancara, Sitompul).

Pada pelaksanaannya perjanjian kredit tidak selamanya berjalan dengan baik di mana nasabah atau debitur terlambat melakukan pembayaran angsuran kredit atau bahkan sama sekali tidak melakukan pembayaran angsuran kreditnya. Pihak bank dalam hal ini bertanggung jawab untuk mengupayakan pengembalian danayang telah dipinjamkan kepada debitur melalui serangkaian kegiatan diantaranya: (Wawancara, Sitompul).

1. Melakukan kunjungan kepada debitur untuk menanyakan dan mengevaluasi beban kredit terkait adanya keterlambatan pembayaran angsuran oleh debitur.

2. Melakukan peninjauan ulang serta menstrukturisasi ulang jumlah angsuran kredit dalam hal debitur sedang mengalami masalah keuangan yang berakibat pada keterlambatan pembayaran angsuran oleh debitur.

3. Memberikan peringatan secara tertulis secara bertahap kepada debitur untuk melakukan pelunasan keterlambatan pembayaran angsuran oleh debitur (Wawancara, Sitompul).

Pihak bank dalam hal telah melaksanakan semua rangkaian kegiatan penagihan pembayaran keterlambatan angsuran kredit kepada debitur sesuai langkah di atas, namun tidak juga berhasil, maka pihak bank dalam hal ini dapat mengambil langkah melakukan pelelangan terhadap jaminan yang ada dalam perjanjian kredit antara bank dengan nasabah atau debitur baik melakukan pelelangan secara langsung dan terbuka untuk umum ataupun melakukan pelelangan melalui badan lelang swasta atau badan lelang Negara (Wawancara, Sitompul).

Kedudukan jaminan yang diagunkan dalam perjanjian kredit perbankan yang selanjutnya digunakan untuk penyelesaian sengketa kredit macet menurut hukum positif adalah diperbolehkan di mana bank sebagai pihak kreditur berupaya mengambil pelunasan piutang dengan penjualan aset jaminan debitur melalui metode lelang eksekusi berdasarkan UndangUndang Nomor 4 Tahun 1996 Tentang Hak Tanggungan Atas Tanah Beserta Benda-Benda Yang Berkaitan Dengan Tanah, dan Undang-Undang Nomor 42 Tahun 1999 Tentang Jaminan Fidusia yaitu melalui parate eksekusi di mana pemegang hak tanggungan, dalam hal ini bank dapat menjual obyek hak tanggungan melalui pelelangan umum serta mengambil pelunasan piutang dari hasil pelelangan umum tersebut (Wawancara, Sitompul). 
Ketentuan Pasal 1 Angka 1 Undang-Undang Nomor 4 Tahun 1996 Tentang Hak Tanggungan Atas Tanah Beserta Benda-Benda Yang Berkaitan Dengan Tanah ini dapat disimpulkan bahwa hak tanggungan adalah hak jaminan atas tanah untuk pelunasan utang tertentu yang memberikan kedudukan yang diutamakan kepada kreditur tertentu terhadapkreditur-kreditur lain (Meliala, 2007, h. 52).

Pada prinsipnya lembaga keuangan bank atau bukan bank akanmeminta jaminan dari pihak debitur yang diikat dengan hak tanggungandengan alasan apabila terjadi wanprestasi (cidera janji) dari pihak debitur,lembaga tersebut akan cepat memperoleh piutangnya kembali, cukup dengan membawa sertifikat hak tanggungan sudah langsung dapat mengajukanpermohonan ekesekusi kepada ketua pengadilan negeri di wilayah mana obyek tanggungan itu berada.

Faktanya pada perjanjian kredit tidak diperlukan lagi karena sertifikat haktanggungan sudah cukup membuktikan adanya utangpiutang antara kreditur dengan debitur. Kreditur pemegang hak tanggungan dalam kedudukannya sebagai kreditur preferen pada prinsipnya mendapat kedudukan yang didahulukan dibandingkan dengan kreditur-kreditur lainnya (Pasal 1133 Ayat (1) Kitab Undang-Undang Hukum Perdata). Kedudukan yang didahulukan ini yaitu hak untuk didahulukan diantara orang-orang berpiutang terbit dari hakistimewa, dari gadai dan dari hipotik, dimana apabila debitur wansprestasi (cidera janji), kreditur pemegang hak tanggungan akan mempunyai hak yang didahulukan dalam pelunasan piutangnya dibandingkan dengan kreditur-krediturlainnya yang bukan pemegang hak tanggungan (Pasal 1133 Ayat (1) Kitab Undang-Undang Hukum Perdata).

Sifat pemenuhan piutang yang didahulukan ini disebut dengan kreditur preferen, didahulukan disini adalah didahulukan dalam mengambil pelunasan ataspenjualan eksekusi benda hipotik (hak tanggungan). Kedudukan preferen (lebih didahulukan) berkaitan dengan hasil eksekusi, akan tampak jelas kalau dihubungkan oleh asas bahwa para kreditur berbagi pond's-pond's harta benda milik debitur dan dengan memperhatikan kepentingan kreditur preferen berhak mengambil lebih dulu uang hasil hipotik (hak tanggungan) (Pasal 1132 ayat 1 Kitab Undang-Undang Hukum Perdata). Sebagaimana Satrio berpendapat bahwa, unsur dari kedudukan yang diutamakan atau didahulukan dari krediturpemegang hak tanggungan adalah berkaitan dengan pelunasan piutangkreditur pemegang hak tanggungan, dan cara pelunasannya yaitu dengan carapenjualan lelang terhadap tanah yang menjadi obyek hak tanggungan (eksekusi hak tanggungan).

Lahirnya Undang-Undang Nomor 4 Tahun 1996 Tentang Hak Tanggungan Atas Tanah Beserta Benda-Benda Yang Berkaitan Dengan Tanah, dan Undang-Undang Nomor 42 Tahun 1999 tentang Jaminan Fidusia yang dirancang memberikan kepastian hukum sebagai hak jaminan yang kuat, dengan ciri khas eksekusi mudah dan pasti namun ternyata dalam pratiknya tidak demikian. Proses penyelesaian kredit bermasalah dengan pelaksanaan lelang jaminan hak tanggungan sering memunculkan perlawanan dari pihak debitur (nasabah) berupa gugatan perdata yang dilayangkan ke pengadilan negeri (Wawancara, Sitompul).

Kedudukan aset debitur sebagai jaminan dalam perjanjian kredit pada PT. Bank Artha Graha Internasional, Tbk Medan yang digunakan untuk penyelesaian sengketa kredit macet merupakan upaya bank untuk mengambil pelunasan perjanjian kredit dengan penjualan aset jaminan debitur melalui metode lelang eksekusi berdasarkan Undang-Undang Nomor 4 Tahun 1996 Tentang Hak Tanggungan Atas Tanah Beserta Benda-Benda Yang Berkaitan Dengan Tanah, dan berdasarkan Undang-Undang Nomor 42 Tahun 1999 Tentang Jaminan Fidusia yang 
dilaksanakan melalui metode parate eksekusi di mana pemegang hak tanggungan, dalam hal ini bank dapat menjual obyek hak tanggungan melalui pelelangan umum serta mengambil pelunasan piutang dari hasil pelelangan umum tersebut.

\section{Proses Penyelesaian Sengketa Kredit Macet Melalui Pelaksanaan Lelang Aset Debitur Oleh PT. Bank Artha Graha Internasional, Tbk Medan}

Resiko atas kredit adalah tidak tertagihnya kredit yang telah disalurkannya, baik pokok pinjaman yang diberikan, maupun bunganya sesuai dengan ketentuan yang berlaku (Ismail, 2011, h. 122).Perkembangan pemberian kredit yang paling tidak menggembirakan bagi pihak bank adalah apabila kredit yang diberikannya ternyata menjadi kredit bermasalah. Hal ini terutama disebabkan oleh kegagalan pihak debitur memenuhi kewajibannya untuk membayar angsuran (cicilan) pokok kredit beserta bunga yang telah disepakati kedua belah pihak dalam perjanjian kredit (Dendawijaya, 2005, h. 82).

Kredit bermasalah merupakan kredit yang telah disalurkan oleh bank, dan nasabah tidak dapat melakukan pembayaran atau melakukan angsuran sesuai dengan perjanjian yang telah di tanda tangani oleh bank dan nasabah. Kredit bermasalah akan berakibat pada kerugian bank, yaitu kerugian karena tidak diterimanya kembali dana yang telah disalurkan, maupun pendapatan bunga yang tidak dapat diterima, artinya bank kehilangan kesempatan mendapatkan bunga, yang berakibat pada penurunan pendapatan secara total (Ismail, 2011, h. 124).

Beberapa pengertian mengenai kategori kolektibilitas kredit berdasarkan ketentuan yang dibuat yaitu sebagai berikut:

1. Kredit lancar, kredit yang tidak mengalami penundaan pengembalian pokok pinjaman dan pembayaran bunga.

2. Kredit dengan perhatian khusus, merupakan kredit yang masih digolongkan lancar, akan tetapi mulai terdapat tunggakan, ditinjau dari segi kemampuan membayar, yang tergolong kredit dalam perhatian khusus apabila terdapat tunggakan angsuran pokok dan/atau bunga sampai dengan 90 (sembilan puluh) hari.

3. Kredit kurang lancar, kredit yang pengembalian pokok pinjaman dan pembayaran bunganya telah melampaui 90 (sembilan puluh) hari sampai dengan kurang dari 180 (seratus delapan puluh) hari dari waktu yang diperjanjikan.

4. Kredit diragukan adalah kredit yang pengembalian pokok pinjaman dan pembayaran bunganya telah mengalami penundaan selama 180 (seratus delapan puluh) hari hingga 270 (dua ratus tujuh puluh) hari atau dua kali dari jadwal yang diperjanjikan.

5. Kredit macet, kredit yang pokok pinjaman dan pembayaran bunganya telah mengalami penundaan melampaui 270 (dua ratus tujuh puluh) hari atau lebih sejak jatuh tempo (Dendawijaya, 2005, h. 82).

Kredit dikategorikan sebagai kredit bermasalah atau non performing loan tersebut adalah apabila kualitas kredit tersebut tergolong pada tingkat kolektibilitas kurang lancar, diragukan, atau macet (Hermansyah, 2011, h. 75). Pada dasarnya, kreditur pemegang jaminan kebendaan memiliki hak untuk mengeksekusi barang jaminan untuk dijual secara lelang guna pembayaran utang debitur jika debitur lalai melaksanakan kewajibannya berdasarkan perjanjian kredit atau biasa disebut dengan wanprestasi. Pemberian hak kepada kreditur untuk mengeksekusi jaminan kebendaan yang diberikan oleh debitur dapat dilihat dalam hukum perdata serta beberapa peraturan perundang-undangan lainnya yaitu sebagai berikut: 
1. Pasal 1155 KUH Perdata.

2. Pasal 15 Ayat (3) Jo. Pasal 29 Undang-Undang Nomor 42 Tahun 1999 Tentang Jaminan Fidusia.

3. Pasal 6 Jo. Pasal 20 Undang-Undang Nomor 4 Tahun 1996 Tentang Hak Tanggungan Atas Tanah Beserta Benda-Benda Yang Berkaitan Dengan Tanah.

Pihak bank dan nasabah dalm hal hendak memperbaiki keadaan problem loan, maka haruslah dikenali masalah yang dihadapi dan dicarikan penyelesaiannya (Latumaerissa, h. 77). Bank harus melaksanakan analisis yang mendalam sebelum memutuskan untuk menyetujui ataupun menolak permohonan kredit dari calon debitur, hal ini dimaksudkan agar tidak terjadi permasalahan atas kredit yang telah disalurkan, akan tetapi meskipun bank telah melakukan analisis yang cermat, resiko kredit bermasalah juga mungkin terjadi, dan tidak ada satu pun bank di dunia ini yang tidak memiliki kredit bermasalah, karena tidak mungkin dari semua kredit yang disalurkan, semuanya lancer (Ismail, 2011, h. 126).

Kredit bank yang telah menjadi bermasalah, tindakan yang harus segera dilakukan oleh pihak bank adalah penyelesaian melalui berbagai cara (Arthesa, Edia, h. 183). Praktek, apabila terdapat debitur yang wanprestasi, biasanya bank akan mengirimkan surat peringatan kepada debitur agar melaksanakan kewajibannya dalam pembayaran angsuran sesuai dengan yang diperjanjikan. Peringatan tersebut biasanya diajukan paling sedikit sebanyak tiga kali untuk memenuhi syarat keadaan wanprestasinya debitur.

Debitur dalam hal telah diperingati secara patut tetapi debitur tidak juga melakukan pembayaran kewajibanya, maka bank melalui ketentuan hukum yang terdapat pada Pasal 6 Jo. Pasal 20 Undang-Undang Nomor 4 Tahun 1996 Tentang Hak Tanggungan Atas Tanah Beserta Benda-Benda Yang Berkaitan Dengan Tanah, akan melakukan proses lelang terhadap jaminan debitur.

Penyelesaian sengketa kredit macet melalui pelaksanaan lelang oleh PT. Bank Artha Graha Internasional, Tbk Medan adalah sebagai langkah pihak bank dalam mengembalikan dana yang dipinjamkan bank kepada debitur, sebab dana yang telah dipinjamkan pada dasarnya harus dikembalikan oleh karena dana tersebut adalah dana milik masyarakat yang dititipkan dan dikelola oleh bank di mana penjualan atas dasar eksekusi dilakukan melalui suatu pelelangan umum. Bank biasanya lebih banyak mengajukan permohonan lelang jaminan hak tanggungan kepada balai lelang swasta, selanjutnya balai lelang swasta akan meneruskan permohonan tersebut kepada KPKNL (Kantor Pelayanan Kekayaan Negara Dan Lelang) yang merupakan salah satu unit kerja pada Direktorat Jenderal Kekayaan Negara Kementerian Keuangan Republik Indonesia.

Balai lelang swasta yang bertindak sebagai fasilitator pelaksanaan lelang, maka landasan aturan hukum yang dipakai adalah Pasal 14 Undang-Undang Nomor 4 Tahun 1996 Tentang Hak Tanggungan Atas Tanah Beserta Benda-Benda Yang Berkaitan Dengan Tanah yang mengisyaratkan bahwa pelaksanaan lelang hak tanggungan memiliki kekuatan eksekutorial yang sama dengan putusan hukum pengadilan yang telah berkekuatan hukum tetap (inkracht van gewijsde) (Latif, Nahrowi, 2009, h. 206). Berdasarkan teori penyelesaian sengketa, pihak bank sebagai pihak yang berwenang dalam melaksanakan penyelesaian sengketa kredit macet yang terjadi antara bank dengan nasabah dalam hal dapat memberikan solusi hukum terkait penyelesaian sengketa yang dapat ditempuh oleh para pihak yaitu sebagai berikut:

1. Penyelesaian masalah melalui media musyawarah. 
2. Penyelesaian masalah melalui non litigasi.

3. Penyelesaian masalah melalui jalur litigasi (Wawancara, Sitompul).

\section{Mekanisme Pelelangan Aset Debitur Terkait Penyelesaian Kredit Macet Antara Nasabah Dengan Pihak PT. Bank Artha Graha Internasional, Tbk Medan}

Kegiatan usaha bank pada dasarnya memiliki banyak resiko di mana dalam menjalankan usahanya perseroan sebagaimana perbankan secara umum dihadapkan pada berbagai resiko yang mempengaruhi hasil usaha maupun kelangsungan usaha apabila resiko tersebut tidak dikelola dengan baik. Resiko usaha utama yang dihadapi perseroan adalah resiko kredit, yakni ketidakmampuan debitur untuk membayar kembali kredit yang diberikan. Semakin besar porsi kredit yang bermasalah karena adanya keraguan atas kemampuan debitur dalam membayar kembali pinjaman yang diberikan, semakin besar pula kebutuhan biaya penyisihan penghapusan kredit, yang pada akhirnya akansangat mempengaruhi keuntungan perseroan.

Resiko lain yang menurut perseroan dapat mempengaruhi kegiatan usahanya adalah resiko likuiditas, resiko pasar, resiko operasional, resiko hukum, dan resiko lainnya, seperti resiko strategi, resiko kepatuhan, dan resiko reputasi (Wawancara, Sitompul). Resiko usaha utama yang dihadapi perseroan adalah resiko kredit, yakni ketidakmampuan debitur untuk membayar kembali kredit yang diberikan. Semakin besar porsi kredit yang bermasalah karena adanya keraguan atas kemampuan debitur dalam membayar kembali pinjaman yang diberikan, semakin besar pula kebutuhan biaya penyisihan penghapusan kredit, yang pada akhirnya akan sangat mempengaruhi keuntungan perseroan.

Pengendalian resiko kredit berawal sejak proses permohonan kredit dilakukan, di mana analisa kelayakan kredit telah diproses melalui pembuatan memorandum analisa kredit oleh account officer dan dilengkapi oleh penggunaan credit risk ratingyang berbasis internet serta pelaksanaan review independen oleh divisi manajemen resiko dan pengujian kepatuhan oleh divisi kepatuhan. Limit kewenangan pemberian persetujuan kredit untuk setiap anggota komite kredit diatur secara ketat dan direview secara berkala oleh komite kredit (Wawancara, Sitompul).

Proses persetujuan kredit dilakukan berdasarkan prinsip bahwa setiap kredit harus diproses melalui komite kredit untuk memperoleh persetujuan. Komposisi, jumlah anggota, dan kewenangan komite kredit berbeda sesuai dengan jumlah dan fasilitas kredit yang diajukan. Kredit yang diberikan dimonitor secara periodik dan penetapan kebijakan monitoring kredit yang dilakukan berdasarkan faktor-faktor yang digunakan dalam proses persetujuan kredit.

Bank juga melakukan pemantauan dan pengkajian atas aktivitas rekening nasabah, kondisi keuangan, kepatuhan terhadap perjanjian kredit, pemenuhan syarat-syarat yang dipersyaratkan oleh komite kredit, kondisi agunan, pembayaran angsuran pokok maupun bunga, kunjungan usaha serta penyelesaian permasalahan kredit non performing yang terjadi. Restrukturisasi kredit dilakukan atas kredit dalam kategori non performing loan dan atas kredit yang diperkirakan akan mengalami kesulitan pembayaran di kemudian hari.

Penyehatan atau penyelamatan kredit bermasalah dapat dilakukan antara lain berupa restrukturisasi kedit, reschedulling atau reconditioning kredit yang dilakukan oleh divisi remedial berkoordinasi dengan divisi kredit dan diatur dalam pedoman internal bank. Tagihan yang telah jatuh tempo adalah seluruh tagihan yaitu tagihan kepada pemerintah, tagihan kepada entitas sektor publik, tagihan kepada bank pembangunan multilateral dan lembaga internasional, tagihan kepada bank, kredit beragun rumah tinggal, kredit beragun properti komersial, kredit pegawai atau pensiun, tagihan kepada usaha mikro, usaha kecil dan portofolio 
ritel dan tagihan kepada korporasi, yang telah jatuh tempo lebih dari(sembilan puluh) hari, baik atas pembayaran pokok dan/atau pembayaran bunga. (Wawancara, Sitompul).

Konsep efektivitas dalam defenisi yang dikemukakan oleh Hens Kalsen difokuskan pada subjek dan sanksi. Subjek yang melaksanakannya, yaitu orang-orang atau badan hukum. Orangorang tersebut harus melaksanakan hukum sesuai dengan bunyinya norma hukum. Bagi orangorang yang dikenai sanksi hukum, maka sanksi hukum benar-benar dilaksanakan atau tidak (Fajaruddin, 2018, h. 207).

Tagihan yang mengalami penurunan nilai atau impairment terjadijika bukti obyektif dan management's expert judgement mengindikasikan bahwa entitas tidak akan memperoleh kembali aset keuangan yang diberikan sesuai jangka waktu yang ditetapkan dalam kontrak perjanjian.Bukti obyektif meliputi satu atau lebih peristiwa yang merugikan yang berdampak pada estimasi future cash flow atas aset keuangan atau kelompok aset keuangan dan untuk memastikan bahwa kerugian penurunan nilai diakui secara tepat waktu, aset keuangan atau kelompok aset keuangan harus direview secara periodikdan evaluasi penurunan dilakukan secara periodik.

Pendekatan yang digunakan untuk pembentukan cadangan kerugian penurunan nilai individual dan kolektif, serta metode statistik yang digunakan dalam perhitungan, bank menentukan penyisihan secara individual untuk masing-masing aset keuangan kredit diberikan individu secara signifikan. Beberapa hal yang dipertimbangkan dalam menentukan jumlah penyisihan antara lain mencakup: (Wawancara, Sitompul).

1. Kemungkinan rencana bisnis debitur.

2. Kemampuan untuk memperbaiki kinerja setelah adanya kesulitan keuangan.

3. Proyeksi penerimaan dan pembayaran apabila terjadi kebangkrutan.

4. Kemungkinan adanya sumber pembayaran lainnya.

Jumlah yang dapat direalisasikan atas jaminan dan ekspektasi waktu arus kas, penyisihan penurunan nilai dievaluasi secara periodik, kecuali bila terdapat beberapa kondisi yang mengharuskan adanya pemantauan yang lebih berhati-hati (Wawancara, Sitompul). Bank dalam rangka meningkatkan prinsip kehati-hatian (prudential principles) dan penerapan sistem peringatan dini (early warning system), maka divisi manajemen resiko dilibatkan dalam siklus proses aktivitas front office, antara lain: (Wawancara, Sitompul).

1. Melakukan review independen kredit terhadap calon debitur atau debitur sesuai batasan atau limit dan ketentuan yang ditetapkan oleh direksi.

2. Melakukan identifikasi dan penilaian resiko atas setiap permohonan penyimpangan dari ketentuan operasi yang diajukan oleh unit kerja operasional sesuai batasan atau limit dan ketentuan yang ditetapkan oleh direksi.

Bank memiliki kegiatan usaha penunjang di mana bank melakukan kegiatan lain yang lazim dilakukan oleh bank sepanjang tidak bertentangan dengan perundang-undangan dan peraturan yang berlaku, termasuk antara lain tindakan dalam rangka restrukturisasi atau penyelamatan kredit antara lain membeli agunan, baik semua maupun sebagian, melalui lelang atau dengan cara lain, dalam hal debitur tidak memenuhi kewajibannya kepada bank, dengan ketentuan agunan yang dibeli wajib dicairkan secepatnya (Wawancara, Sitompul).

Bank dalam mengatasi resiko atau ketidakmampuan debitur dalam membayar kembali pinjaman yang diberikan pada umumnya melakukan permohonan ekesekusi kepada ketua pengadilan negeri di wilayah mana obyek tanggungan itu berada dengan membawa sertifikat hak tanggungan, namun sebelum sampai pada tahap ini ada mekanisme yang harus di lewati 
pihak bank sebelum melakukan pelelangan objek yang menjadi jaminan dalam perjanjian kredit bank.

Adapun penyelesaian kredit macet antara nasabah dengan pihak PT. Bank Artha Graha Internasional, Tbk Medan antara lain: (Wawancara, Sitompul).

1. Pihak bank melakukan kunjungan kepada debitur untuk menanyakan dan mengevaluasi beban kredit terkait adanya keterlambatan pembayaran angsuran oleh debitur.

2. Pihak bank melakukan peninjauan ulang serta menstrukturisasi ulang jumlah angsuran kredit dalam hal debitur sedang mengalami masalah keuangan yang berakibat pada keterlambatan pembayaran angsuran oleh debitur.

3. Pihak bank memberikan peringatan secara tertulis secara bertahap kepada debitur untuk melakukan pelunasan keterlambatan pembayaran angsuran oleh debitur.

Pihak bank dalam hal telah melaksanakan semua rangkaian kegiatan penagihan pembayaran keterlambatan angsuran kredit kepada debitur sesuai langkah di atas, namun tidak juga berhasil, maka pihak bank dalam hal ini dapat mengambil langkah melakukan pelelangan terhadap jaminan yang ada dalam perjanjian kredit antara bank dengan nasabah atau debitur baik melakukan pelelangan secara langsung dan terbuka untuk umum ataupun melakukan pelelangan melalui badan lelang swasta atau badan lelang negara, dan untuk penyelesaian piutang bank yang sudah diserahkan kepada badan urusan piutang dan lelang negara atau panitia urusan piutang negara, maka pelaksanaan lelang dilaksanakan olehpejabat badan urusan piutang dan lelang negara atau panitia urusan piutang Negara (Wawancara, Sitompul).

Adapun mekanisme yang dilakukan dalam pelelangan aset debitur oleh PT. Bank Artha Graha Internasional, Tbk Medan antara lain: (Wawancara, Sitompul).

1. Pihak bank akanmelakukan pelelangan secara terbuka baik melakukan pelelangan sendiri atau menggunakan balai lelang negara ataupun balai lelang swasta.

2. Pihak bank memasukkan data-data terkait barang yang akan di lelang dalam hal bank menggunakan jasa balai lelang negara ataupun balai lelang swasta.

3. Pihak bank bersama-sama balai lelang negara ataupun balai lelang swasta membuat pengumuman bahwa benda jaminan nasabah akan dilelang melalui pelelangan umum dan terbuka.

4. Pihak bank bersama-sama balai lelang negara ataupun balai lelang swasta membuat limit jaminan lelang yang harus dibayarkan oleh peserta lelang.

5. Pihak bank bersama-sama balai lelang negara ataupun balai lelang swasta menentukan hari pelaksanaan lelang.

6. Pihak bank bersama-sama balai lelang negara ataupun balai lelang swasta menentukan pemenang lelang.

7. Pihak bank bersama-sama balai lelang negara ataupun balai lelang swasta mengeluarkan risalah lelang sebagai bukti bahwa barang jaminan tersebut sudah berhasil terjual melalui pelelangan.

Mekanisme pelelangan aset debitur terkait penyelesaian kredit macet antara nasabah dengan pihak PT. Bank Artha Graha Internasional, Tbk Medan antara lain pihak bank akan melakukan pelelangan secara terbuka baik melakukan pelelangan sendiri atau menggunakan balai lelang negara ataupun balai lelang swasta. Bank biasanya lebih banyak mengajukan permohonan lelang jaminan hak tanggungan kepada balai lelang swasta, selanjutnya balai lelang swasta akan meneruskan permohonan tersebut kepada KPKNL (Kantor Pelayanan 
Kekayaan Negara Dan Lelang) yang merupakan salah satu unit kerja pada Direktorat Jenderal Kekayaan Negara Kementerian Keuangan Republik Indonesia. Sebaiknya pihak bank dalam hal pelaksanaan lelang aset debitur harus melaksanakannya sesuai dengan mekanisme yang telah di atur oleh undang-undang, hal ini dimaksudkan agar hak-hak debitur dapat terlindungi dengan sebaik-baiknya.

\section{KESIMPULAN}

Eksistensi aset debitur yang dilaksanakan melalui metode parate eksekusi di mana pemegang hak tanggungan, dalam hal ini bank dapat menjual obyek hak tanggungan melalui pelelangan umum serta mengambil pelunasan piutang dari hasil pelelangan umum tersebut. Proses penyelesaian sengketa kredit macet melalui pelaksanaan lelang aset debitur oleh PT. Bank Artha Graha Internasional, Tbk Medan dapat dilaksanakan melalui beberapa cara diantaranya melalui jalan musyawarah, melalaui metode alternatif penyelesaian sengketa dan langkah terakhir adalah melalui proses litigasi. Mekanisme pelelangan aset debitur terkait penyelesaian kredit macet antara nasabah dengan pihak PT. Bank Artha Graha Internasional, Tbk Medan antara lain pihak bank akan melakukan pelelangan secara terbuka baik melakukan pelelangan sendiri atau menggunakan balai lelang negara ataupun balai lelang swasta. Bank biasanya lebih banyak mengajukan permohonan lelang jaminan hak tanggungan kepada balai lelang swasta, selanjutnya balai lelang swasta akan meneruskan permohonan tersebut kepada KPKNL (Kantor Pelayanan Kekayaan Negara Dan Lelang) yang merupakan salah satu unit kerja pada Direktorat Jenderal Kekayaan Negara Kementerian Keuangan Republik Indonesia. Penerapan klausul baku dalam perjanjian terkait jaminan juga perlu adanya prinsip keterbukaan maupun prinsip kehati-hatian antara debitur dan kreditur sehingga terjalinnya kerjasama yang baik dan sehat.

\section{SARAN}

Sebaiknya sebelum melakukan penjualan jaminan atau aset debitur melalui metode lelang, pihak bank memberitahukan secara tertulis kepada debitur terkait jaminan atau aset debitur akan dilakukan penjualan secara lelang, hal ini dimaksudkan jika debitur masih memiliki iktikad baik, maka debitur dapat segera mungkin melakukan pembayaran keterlambatan angsuran kreditnya. Sebaiknya untuk menjamin kepastian hukum dalam pelaksanaan lelang aset debitur, pihak bank menggunakan permohonan fiat eksekusi kepada ketua pengadilan negeri setempat, hal ini dimaksudkan agar tidak timbul permasalahan laindi kemudian hari. Pihak bank dalam hal pelaksanaan lelang aset debitur harus melaksanakannya sesuai dengan mekanisme yang telah di atur oleh undang-undang, hal ini dimaksudkan agar hak-hak debitur dapat terlindungi dengan sebaik-baiknya. Dan, debitur dijelaskan mengenai segala objek yang diperjanjikan dan status saat atau kemudian hari mengenai objek yang dijaminkan. 


\section{DAFTAR PUSTAKA}

Arthesa, Ade. (2006). Bank Dan Lembaga Keuangan Bukan Bank. Jakarta: Indeks.

Dendawijaya, Lukman. (2005). Manajemen Perbankan. Jakarta: Ghalia Indonesia.

Djumhana, Muhammad. (2000). Hukum Perbankan Di Indonesia. Bandung: Citra Aditya Bakti. Fajaruddin. (2018). Efektivitas Undang-Undang Nomor 33 Tahun 2014 Tentang Jaminan Produk Halal Dalam Perlindungan Konsumen. De Lega Lata Jurnal Ilmu Hukum Fakultas Hukum Umsu. 3 (2). 204-216. Https://doi.org/10.30596/dll.v3i2.3151.

Hart, H.L.A. (1997). The Concept of Law. New York: Clarendon Press-Oxford.

Hermansyah. (2011). Hukum Perbankan Nasional Indonesia. Jakarta: Kencana.

Ibrahim, Johnny. (2005). Teori Dan Metedologi Penelitian Hukum Normatif. Malang: Bayumedia.

Ismail. (2011). Manajemen Perbankan Dari Teori Menuju Aplikasi. Jakarta: Kencana.

Kitab Undang-Undang Hukum Perdata

Latif, Al-Azharudin., Nahrowi. (2009). Pengantar Hukum Bisnis Pendekatan Hukum Positif Dan Hukum Islam. Jakarta: Lembaga Penelitian UIN.

Lubis, Mhd. Teguh Syuhada. (2019). Pelaksanaan Sita Jaminan Terhadap Objek Sengketa Yang Berada Di Tangan Pihak Ketiga Dalam Penanganan Perkara Perdata. De Lega Lata Jurnal Ilmu Hukum Fakultas Hukum Umsu. 4 (1). 42-53. https://doi.org/10.30596/dll.v4i1.3163.

Meliala, Djaja S. (2007). Perkembangan Hukum Perdata Tentang Benda Dan Hukum Perikatan. Bandung: Nuansa Aulia.

Ramadhani, Rahmat., Ramlan. (2019). Perjanjian Build Operate And Transfer (BOT) Lapangan Merdeka Medan Dalam Pandangan Hukum Adminsitrasi Negara Dan Hukum Bisnis. De Lega Lata Jurnal Ilmu Hukum Fakultas Hukum Umsu. 4 (2). 255-270. Https://Doi.Org/10.30596/Dll.V4i2.3182.

Sjahdeni, Sutan Remy. (1993), Kebebasan Berkontrak Dan Perlindungan Yang Seimbang Bagi Pihak Dalam Perjanjian Kredit Bank Di Indonesia. Jakarta: Institut Bankir Indonesia.

Sugiyono. (2009). Metode Penelitian Kuantitatif, Kualitatif Dan R\&D. Bandung: Alfabeta.

Wawancara dengan Bapak Johanes Sitompul, Divisi Remedial Dan Collection Pada PT. Bank Artha Graha Internasional, Tbk Cabang Cemara Asri Kota Medan, Pada Tanggal 4 Maret 2019.

Undang-Undang Nomor 10 Tahun 1998 Tentang Perubahan Atas Undang-Undang Nomor 7 Tahun 1992 Tentang Perbankan.

Undang-Undang Nomor 30 Tahun 1999 Tentang Arbitrase Dan Alternatif Penyelesaian Sengketa.

Undang-Undang Nomor 4 Tahun 1996 Tentang Hak Tanggungan Atas Tanah Beserta BendaBenda Yang Berkaitan Dengan Tanah.

Undang-Undang Nomor 42 Tahun 1999 Tentang Jaminan Fidusia. 